\title{
Teacher Professional Development and Geography Teachers' Pedagogical Practices for Climate Change Education
}

\author{
Muofhe Thenga, Paul Goldschagg, René Ferguson, Caleb Mandikonza \\ University of the Witwatersrand
}

\begin{abstract}
Education for Sustainable Development (ESD) was added to the South African Geography school curriculum when the Curriculum Assessment Policy Statement (CAPS) was implemented from 2012. Many in-service teachers who qualified prior to 2014 did not cover this concept during their initial teacher education qualification because it was not part of the curriculum at that time. To address this deficiency, a teacher professional development (TPD) module was developed by the Fundisa for Change programme and offered to a selection of in-service high school Geography teachers. Transformative learning theory helped to understand the pedagogical practices used by teachers after attending the Fundisa for Change teacher professional development programme, in particular the use of a learner-centred approach. Using a small-scale, qualitative and interpretive case study method, the influence of this short TPD course on the teaching of climate change in the Geography CAPS curriculum on teachers' pedagogical practices was investigated. Data were collected through semi-structured interviews, document analysis and lesson observations. Data were analysed using both inductive thematic and deductive analysis. Findings from this small sample of five teachers and their practices suggest that despite attending the programme, most of the participating teachers did not sufficiently integrate climate change education in their Geography classroom practices. The majority of the research participants did not implement the learner-centred teaching methods covered in the course. It is therefore recommended that a teacher professional development programme should be incorporated into longer-term and preferably ongoing professional development programmes so as to adequately foster climate change education in classroom practices.
\end{abstract}

Keywords: Geography, Education for Sustainable Development (ESD), climate change education, teacher professional development, learner-centred pedagogies

\section{Introduction and background}

This paper is drawn from a larger study on the influence of a short teacher professional development course in Education for Sustainable Development (ESD) in Geography teaching 
in secondary schools (Thenga, 2020). ESD was added to the Curriculum Assessment Policy Statement (CAPS) (Department of Basic Education, 2011) curriculum from 2011, meaning that most in-service teachers did not cover this content in their initial teacher qualification. The Geography specific aims in CAPS address the commitment towards sustainable development and making judgements about social and environmental issues (Department of Basic Education, 2011). To respond to this challenge, the Fundisa for Change programme was used to train secondary school Geography teachers using the Teaching Climate Change manual. Fundisa for Change is a South African national programme that aims to develop teachers' knowledge and skills, strengthen the teaching of environmental concepts in schools and encourage teachers to develop values and ethics needed for a more just and sustainable society (Fundisa for Change, 2013). Fundisa for Change is a collaborative programme established by a range of partners including the Department of Environmental Affairs and Tourism, Rhodes University and other higher education institutions, the South African National Biodiversity Institute, the GreenMatter Programme, to enhance transformative environmental learning through teacher education within the CAPS framework (Fundisa for Change, 2013). It aims to develop teachers' subject knowledge, teaching and assessment practices (Fundisa for Change, 2013). Fundisa for Change used climate change to address environmental and sustainable development concerns in different topics in the Geography CAPS curriculum.

The Intergovernmental Panel on Climate Change (IPCC, 2015) defines climate change as the state of the climate that can be identified by the changes and variability of its properties that persists for a long period. Ferguson (2019) argued that climate change refers to the alteration of the composition of the atmosphere which is attributed directly and indirectly to human activities. According to Anderson (2012), climate change education offers an opportunity for people to act in order to reduce the impacts of climate change. Anderson (2012) further argued that climate change education is geared towards learning how to change lifestyles, economies and social structure that are based on excessive production of greenhouse gases.

The research question that guided this paper was: What teaching practices do teachers resort to when teaching environment and sustainability content knowledge?

\section{Literature review}

Teaching and learning for sustainable development requires teachers to adopt a more transformative stance (Smith, 2013), where learners are encouraged to think critically and reflect on issues around them. Smith (2013) further posited that teachers need to develop appropriate pedagogies that enable them to "understand the need for learners to develop skills to question the embedded cultural values, actively identify and assess, communicate and resolve real environmental problems" (p. 261). Teachers therefore need to be empowered so that they are confident to use pedagogies that are appropriate to teach for, and about the environment and sustainable development effectively. This paper focuses on teachers who were trained through the Fundisa for Change programme; their teaching 
pedagogies were analysed to determine the extent of transformation or improvement in their teaching after attending the climate change education course.

\section{Climate change and climate change education}

This section contextualises climate change and climate change education given that they have been defined in the introduction above. According to Anderson (2012), climate change causes hazards which include heat waves, flooding, droughts, intense tropical cyclones, rising sea levels and a loss of biodiversity. These hazards increase vulnerability to disasters resulting in economic and environmental losses. Vulnerable groups such as communities living in poverty in low income countries with poorly functioning education systems, and poor governance are hardest hit by climate change (Anderson, 2012). Codero, Centeno and Todd (2020) noted that the use of education as a climate change mitigation technique is still untested, but its potential to reduce carbon emissions may be realised based on the educational approach utilised. Fundisa for Change is guided by and proposes a transformative learning framework on teachers' practice, which seeks to further influence learner understanding and action.

Stevenson, Nicholls and Whitehouse (2017) maintained that climate change education involves preparing young people for a rapidly changing, uncertain, risky and possibly destructive future. Stevenson et al. (2017) further proposed that the goal of climate change education is to prepare learners for an uncertain future by helping them gain knowledge, skills, dispositions and values that will enable them to deal with future challenges. This requires teachers to use teaching and learning approaches that empower learners to adapt and be resilient to change. Monroe et al. (2019) argued that climate change education should focus on making climate change relevant and meaningful for learners, and that the activities or interventions must engage learners and result in a shift in their beliefs and perspectives.

Anderson (2012) asserted that climate change education fits well within the ESD agenda because it emphasises the empowerment of communities and citizens, engages with issues such as human rights, poverty reduction, sustainable livelihoods, environmental education and gender equality in an essential manner. Vogel, Misser and Vallabh (2013) argued that the CAPS Geography curriculum topics in the Further Education and Training (FET) phase can be taught using climate change units, namely, energy exchange, resource use and change, and responses to energy exchanges and climate change. For instance, the Grade 11 topic on energy balance can be classified under 'energy exchange'; the impacts of droughts and floods, and resource use and sustainability are classified under 'energy resource use and change'; while people's responses to droughts and floods are classified under 'responses to energy exchange and climate change' (Vogel et al., 2013). Empowerment of learners requires them to obtain relevant skills such as critical thinking, problem solving and collaboration which can be used to deal with uncertain futures. There is thus a need to build the capacity of teachers in order to improve their content knowledge and teaching practices for the benefit of learners. 


\section{Teacher professional development programme}

Teacher professional development (TPD) refers to in-service teacher education that can improve teachers' subject content knowledge and hence their teaching practices. Several researchers have examined TPD courses internationally and in South Africa in order to understand their effectiveness in the process of teaching and learning (Steyn, 2008; Darling-Hammond \& McLaughlin, 2010; Ono \& Ferreira, 2010; Avalos, 2011; Ferreira, 2014; Patton, Parker \& Tannehill, 2015). These researchers found that TPDs strengthen teachers' content knowledge and skills. Avalos (2011, p. 10) argued that TPD "is about teachers learning, learning how to learn, and transforming their knowledge into practice for the benefit of their students' growth". This means that TPD has the potential to transform teachers' knowledge and skills to improve learners' performance.

Avalos (2011) and Patton et al. (2015) classified TPD programmes as either individual or collaborative. Individual teacher development focuses on personal and professional growth of independent teachers (Patton et al., 2015) while collaborative programmes focus on the development of teachers as a community or in partnership with one another (Avalos, 2011; Darling-Hammond \& McLaughlin 2011; Patton et al., 2015). Fundisa for Change is a collaborative programme that aims to develop teachers in partnership with one another. Some TPD programmes are occasional and are referred to as short intervention programmes in this paper. Such programmes rely on experts that are external to the Department of Basic Education. Steyn (2008) argued against short intervention courses highlighting that their simplistic and technical view of teaching make people assume that teachers' knowledge and skills could be improved by using external experts. Ono and Ferreira (2010), Steyn (2008) and Nawab (2017) all maintained that short intervention programmes are less likely to result in improvements in the teaching and learning process when compared to continuous programmes because they are isolated from classroom situations. The Fundisa for Change programme which offered a Climate Change module was an example of a short programme which was isolated from the classroom situation.

TPD programmes can take place on or away from the school site. Ferreira (2014) contended that development actions that are implemented away from school settings might help teachers experience things in new ways and can contribute to incidental learning. This implies that the location that is chosen to host the TPD might have an influence on teachers' learning. The Fundisa for Change short intervention course was established to upgrade and develop in-service Geography teachers' knowledge and skills on environmental learning away from their school sites in 2016; it was conducted over a period of five days and was hosted at the Delta Environment Centre. The programme was conducted in the context of content knowledge, teaching practice, assessment and values in education, but this paper is mostly concerned with teaching practice.

\section{Transformative teaching strategies}

CAPS aims to produce learners who are able to identify and solve problems, and make decisions using critical and creative thinking (Department of Basic Education, 2011). 
UNESCO (2012) suggested that the use of a variety of teaching techniques helps learners to develop skills and capacity to learn and think critically. UNESCO (2012) further stipulated that the utilisation of a variety of teaching techniques implies that the needs of individual learners are likely to be considered in planning and delivering lessons. To this end, teachers are expected to attend to diverse needs of learners during the teaching and learning process. Development of skills to teach for and about ESD is one of the aspects that motivated Fundisa for Change to offer training to the secondary school Geography teachers through a short intervention course.

Ferreira (2014) distinguished between teaching styles and argued that the pedagogies that are required to teach for and about ESD should be different from traditional teaching styles. Kalumba (2017) agreed and stressed interdisciplinary, holistic, enquiry-based, experiential and action-oriented methods in teaching ESD. Further, Mokuku and Jobo (2017) emphasised the importance of outdoor learning, experiments and peer tutoring in environmental learning. Laurie et al. (2016) affirmed this view as they showed that teaching practices which are associated with ESD stimulate students to ask questions, think critically and make good decisions about the environment. Thus, teachers should have the ability to use a wide range of pedagogical approaches in order to teach environment and sustainability effectively. Monroe et al. (2019), in reviewing research, identified effective teaching strategies for climate change education as those designed to engage learners such as those associated with experiential, inquiry-based and constructivist approaches. They further stated that deliberative discussion, interaction with science and scientists, addressing misconceptions regarding climate change and working on school and community projects, is effective when teaching controversial topics.

However, Borg et al. (2012) and Raselimo and Wilmot (2013), from observations on teaching approaches mainly used in Swedish schools and Lesotho respectively, found that most teachers do not utilise learner-centred approaches in their classroom practice. This means that even though learner-centred approaches are deemed to be useful for learning, teachers do not always use them in the classroom. The teaching approaches that teachers do use may be linked to the resources they choose for topics within the curriculum.

\section{Theoretical framework}

Mezirow's (1991; 1997; 2000; 2003) transformative learning theory was applied to understand and explain pedagogical practices used in secondary Geography classrooms in relation to the knowledge gained from the Fundisa for Change teacher professional development programme. Cranton and King (2003) argued that the core of transformative learning is that we make meaning through our experiences. They further argued that the process of meaning making develops our frame of reference. According to Mezirow (2000), a frame of reference is the structure of assumptions or expectations through which we filter ideas formed within or outside our consciousness. Mezirow (1997) argued that frames of reference are made up of 'habits of mind' which are broad habitual ways of thinking, feeling and acting. These habits of mind determine our lived experiences and actions. In the Fundisa 
for Change programme, teachers were expected to transform their pedagogical practices in teaching for and about ESD after attending an intervention course. The transformation of pedagogical practices requires teachers' frames of reference to be transformed or expanded.

In order to change frames of reference, individuals need to challenge their existing meaning schemes in relation to new experiences. Mezirow (2003, p. 58) argued that "transformative learning is learning that transforms problematic frames of reference to make them more inclusive, discriminating, open, reflective and emotionally able to change". This means that transformation of frames of reference grants individuals the right to choose, to be open to different viewpoints and to include other points of view in such a way that they make meaning and can reflect on those views for change to occur. Therefore, teachers should shift from using traditional teaching approaches to learner-centred approaches. That shift would mean that their frames of reference have been transformed.

The transformation of frames of reference involves learning, critical reflection and reflective discourse (Mezirow, 2000). Cranton and King (2003) were of the opinion that transformative learning takes place when teachers critically examine their practice and acquire alternative ways of understanding what they do. Learning new meaning and critical reflection based on the knowledge obtained from the intervention course may enable individuals to examine and possibly change deeply-held assumptions. The purpose of employing transformative learning theory in this paper was to indicate how participating teachers transform their teaching practices for teaching ESD after attending a course.

In the next section, the methodology used to investigate the influence of the course on teaching approaches used by the educators is discussed.

\section{Methodology}

The study was conducted using an interpretive qualitative research design. Merriam (2002) argued that interpretive qualitative research allows researchers to learn how individuals experience and interact with the social world and the meaning they derive from it. This study sought to understand teachers' experiences of classroom practices after the course. The case study approach was employed with multiple embedded cases to substantiate the results by comparing and contrasting findings (Vohra, 2014). The Fundisa for Change teacher development course was the main case, while the five participating teachers at different school sites were cases embedded within the main case. Fourteen secondary school teachers participated in the Fundisa for Change course in March 2016. Five of these teachers were purposively selected to take part in the study to establish if they were implementing what they had learnt in their classroom practices.

Data were generated through:

- the analysis of the Teaching Climate Change manual (a manual used by the Fundisa for Change programme for training Geography teachers);

- one-on-one semi-structured interviews with teacher participants were conducted once; and 
- three lesson observations per teacher participant.

This was done in order to ensure triangulation (Creswell, 2012) and validate the responses from different sources. Data were generated in August and September 2017 and January 2018. Semi-structured interviews were chosen because they allowed the researchers to interact with the participants in the process of generating data and enabled probing of key points. The interviews were conducted to establish classroom practices before and after the course in order to determine if participants transformed their practices after the course. Three lessons were observed per teacher in Grade 11 and 12 classes to obtain in-depth interpretation of classroom practices. To preserve anonymity and confidentiality, the participants are referred to as Teachers A, B, C, D and E.

Thematic content analysis which is a method of identifying patterns or themes of meaning across datasets in relation to the research questions (Ngulube, 2015) was applied in the analysis of data. Codes and themes were identified inductively and deductively (Boyatzis, 1998). Inductive analysis means that themes are generated from the data, whilst conclusions are drawn from the previous known facts or definitions, based on the theory in deductive analysis (Javadi \& Zarea, 2016). Inductive analysis considered the intended outcomes of the course, what participating teachers said during interviews, and what teachers did during lesson observations. Deductive analysis was conducted through determining evidence of transformative learning in the teaching strategies used by participating teachers to teach for and about ESD after the course.

\section{Findings}

The findings are structured according to the themes derived deductively from the research questions. These are discussed in terms of the five cases embedded into the Fundisa for Change intervention course. The participating teachers learned different teaching strategies from the intervention course which included experiential, active and investigative teaching strategies as shown in Table 1. Each teaching strategy was linked to skills that could be developed in learners. The participating teachers were expected to use the teaching strategies taught in the intervention course to teach environment and sustainability or to use other learner-centred approaches in their classroom practices. 
Table 1: Teaching strategies taught in the Fundisa for Change course

\begin{tabular}{|c|c|c|}
\hline $\begin{array}{l}\text { Approaches } \\
\text { to teaching }\end{array}$ & Teaching strategies & Skills development \\
\hline \multirow{4}{*}{$\begin{array}{l}\text { Experiential } \\
\text { learning }\end{array}$} & Experiential learning & $\begin{array}{l}\text { Learners experience the world through senses or } \\
\text { emotions }\end{array}$ \\
\hline & Investigative methods & Help learners to collect information from different sources \\
\hline & Information transfer & $\begin{array}{l}\text { Can take the form of class notes, lecture, brochure, poster, } \\
\text { field trip or experiment. Mostly combined with other } \\
\text { methods }\end{array}$ \\
\hline & Deliberative methods & $\begin{array}{l}\text { Provide different viewpoints, scenarios or possible futures } \\
\text { for learners to think, predict or debate about }\end{array}$ \\
\hline \multirow{4}{*}{$\begin{array}{l}\text { Active } \\
\text { meaning } \\
\text { making }\end{array}$} & Scenario (using case studies) & Involves making predictions \\
\hline & Learning by doing & $\begin{array}{l}\text { Project work on vulnerabilities and practical activities } \\
\text { that can make communities resilient }\end{array}$ \\
\hline & $\begin{array}{l}\text { Fieldwork and collaborative } \\
\text { research }\end{array}$ & For research purposes \\
\hline & Role play and debate & $\begin{array}{l}\text { Help learners explore and put themselves in the shoes of } \\
\text { other people and then report findings }\end{array}$ \\
\hline \multirow{3}{*}{$\begin{array}{l}\text { Integration } \\
\text { of methods }\end{array}$} & $\begin{array}{l}\text { Combining investigative, } \\
\text { deliberative and learning by } \\
\text { doing }\end{array}$ & $\begin{array}{l}\text { Learners collect information from different sources, } \\
\text { provide different viewpoints, scenarios or possible futures } \\
\text { for learners to think, predict or debate about and do } \\
\text { practical activities or projects }\end{array}$ \\
\hline & Critical deliberation & Helps in negotiations \\
\hline & Values clarification & $\begin{array}{l}\text { Involves dialogue - learners are encouraged to challenge } \\
\text { their views and values }\end{array}$ \\
\hline
\end{tabular}

Table 2: Teachers' responses - Data from interviews

\begin{tabular}{|l|l|l|}
\hline & Teaching methods used before the course & Teaching methods used after the course \\
\hline Teacher A & $\begin{array}{l}\text { Textbook based method, where she read } \\
\text { lesson material directly from the textbook } \\
\text { for the learners }\end{array}$ & $\begin{array}{l}\text { Learner-centred teaching methods (but she } \\
\text { could not elaborate on the learner methods } \\
\text { she used) }\end{array}$ \\
\hline Teacher B & Textbook based method & $\begin{array}{l}\text { Learner-centred teaching methods (but she } \\
\text { could not elaborate on the learner methods } \\
\text { she used) }\end{array}$ \\
\hline Teacher C & $\begin{array}{l}\text { Textbook based method and fieldwork } \\
\text { within the school }\end{array}$ & $\begin{array}{l}\text { Textbook based method and fieldwork } \\
\text { within the school }\end{array}$ \\
\hline Teacher D & Information transfer & $\begin{array}{l}\text { Information transfer, research, fieldwork, } \\
\text { smartboard and cellphones }\end{array}$ \\
\hline Teacher E & Story-telling, pictures and videos & Story-telling, pictures and videos \\
\hline
\end{tabular}


Evidence from lesson observations revealed that what participating teachers said during interviews was aligned with what transpired during observations of teaching and learning in terms of teaching strategies.

Figure 1: Data from lesson observations

\begin{tabular}{|c|c|c|c|c|}
\hline Teacher A & Teacher B & Teacher C & Teacher D & Teacher E \\
\hline $\begin{array}{l}\text { Relied on reading } \\
\text { for information in } \\
\text { the three lessons } \\
\text { she taught in the } \\
\text { Grade } 11 \text { class. } \\
\text { The lessons } \\
\text { that Teacher } \\
\text { A taught were } \\
\text { on the concept } \\
\text { of sustainable } \\
\text { development, } \\
\text { monsoon winds } \\
\text { and fohn winds. }\end{array}$ & $\begin{array}{l}\text { Used reading } \\
\text { for information, } \\
\text { information } \\
\text { transfer, class } \\
\text { discussion, } \\
\text { dialogue, and } \\
\text { question and } \\
\text { answer methods } \\
\text { to teach the } \\
\text { informal sector } \\
\text { and travelling } \\
\text { disturbances }\end{array}$ & $\begin{array}{l}\text { Used reading } \\
\text { for information, } \\
\text { class discussion, } \\
\text { group discussion, } \\
\text { and question and } \\
\text { answer methods } \\
\text { when teaching } \\
\text { the Grade } 11 \\
\text { section on South } \\
\text { Africa's long-term } \\
\text { strategy using } \\
\text { conventional } \\
\text { energy sources } \\
\text { and another } \\
\text { lesson on drought. } \\
\text { Teacher C used } \\
\text { the same methods } \\
\text { in teaching } \\
\text { anabatic and } \\
\text { catabatic winds to } \\
\text { the Grade } 12 \text { class. }\end{array}$ & $\begin{array}{l}\text { Used information } \\
\text { transfer, class } \\
\text { discussion, } \\
\text { dialogue and } \\
\text { questions } \\
\text { and answers } \\
\text { when teaching } \\
\text { resource use and } \\
\text { sustainability to } \\
\text { the Grade } 11 \text { s. } \\
\text { In a Grade } 12 \\
\text { class, Teacher } \\
\text { D employed } \\
\text { information } \\
\text { transfer, class } \\
\text { discussion and } \\
\text { the question and } \\
\text { answer teaching } \\
\text { strategy. }\end{array}$ & $\begin{array}{l}\text { Made use of } \\
\text { writing notes, } \\
\text { explaining the } \\
\text { notes and asking } \\
\text { question when } \\
\text { teaching lessons } \\
\text { on trade and } \\
\text { development and } \\
\text { using resources } \\
\text { in Grade } 11 . \text { In } \\
\text { the third lesson } \\
\text { observed, Teacher } \\
\text { E was observed } \\
\text { teaching soil } \\
\text { and soil profiles, } \\
\text { and she made } \\
\text { use of fieldwork } \\
\text { observation } \\
\text { within the school } \\
\text { yard, media } \\
\text { and reading for } \\
\text { information. }\end{array}$ \\
\hline
\end{tabular}

It was evident that most of the participants relied on reading from the textbooks, discussion and information transfer. Of the five participants, Teacher E tried to apply various learnercentred teaching approaches which would enhance learners' understanding. However, one cannot tell whether she learned this from the course or not. Consequently, four of the five participants' teaching strategies do not reflect change since they continued using the methods they used before attending the course.

\section{Discussion}

Borg et al. (2012) contended that traditional teaching from the front of the class was still a common teaching method in Swedish schools, even though it is utilised in combination with other approaches. Borg et al. (2012) further argued that the commonly used teaching methods in teaching sustainable development in Swedish schools are discussion, lectures, small group research, interdisciplinary work and class debates. The teaching strategies used in Sweden were possible because of the smaller class sizes in developed countries as opposed to larger class sizes in developing countries. In a study conducted in Lesotho, Raselimo and Wilmot (2013) found that teachers after ESD training did not adopt teaching strategies 
that encouraged learner participation. Most teachers participating in our study at the time of data collection did not implement learner-centred teaching strategies, except Teacher E who did implement a few of these methods. It seemed most participating teachers were reluctant to try the methods taught in the Fundisa for Change course or did not know how to apply them. Participating teachers were comfortable with the way they were teaching. They also did not know how to apply the methods because the course which introduced the methods did not give them a chance to practice what they learnt during the course. They would have preferred a hands-on course with practical activities, which they could have taken directly into their classrooms. Applying transformative teaching strategies in teaching climate change education might help because learners are engaged on issues that are more relevant and meaningful to their lives (Monroe et al., 2019). Anderson (2012) stated that engaging learners in teaching climate change education helps in empowering them and their communities.

Steyn (2008), Ono and Ferreira (2010) and Nawab (2017) all argued that short teacher professional development programmes are unlikely to result in transforming classroom practices. To ensure that learners acquire knowledge and skills that promote sustainable development, teachers need to transform their thinking and action, which will in turn transform their classroom practices. The Fundisa for Change short intervention course was not sufficient to bring about change in teaching approaches and the use of a variety of resources in teaching for and about ESD. This paper supports the views that have been advanced by Steyn (2008), Ono and Ferreira (2010) and Nawab (2017) that professional development is more effective when it is a continuous process.

\section{Conclusion}

This paper explored the influence of the Fundisa for Change short TPD course on pedagogical practices for ESD. Teachers who participated in this course were exposed to a variety of learner-centred teaching approaches and different resources that could be used to teach for and about ESD. While the course sought to transform teachers' practices in order to develop learners' skills and critical thinking, its effectiveness was doubtful. Attending the Fundisa for Change course required teachers' frames of reference and pedagogical practices to be transformed or expanded. However, it would seem that simply attending the course was not sufficient to transform most of the participating teachers' frames of reference as envisaged by Mezirow (1991). This conclusion is based on the lack of change in teaching practices following the course. This could be because of the rigid structure of the curriculum where teachers were focusing on satisfying its demands instead of innovating and changing their teaching approaches. Only one of the five teacher participants varied their teaching approaches and resources in teaching for and about ESD. This suggests that teaching practices could be better supported through a follow-up TPD session where teachers could be invited to share ideas and experiences of what works and where they struggled and need help. Teachers could also be encouraged to bring examples of their work and experiences, for discussion in a constructive learning environment. 
Rising temperatures and consequent climate change are serious problems facing future generations since extreme weather events become worse and occur more frequently. These are sufficient reasons alone for educators to be equipped to teach their learners effectively about the problems humanity has caused, and measures urgently needed to bring about change.

\section{Notes on Contributors and their Contributions}

\section{Lead author}

Thenga, Muofhe

Muofhe Thenga holds a PhD from the University of the Witwatersrand. Her interests include professional development of teachers through Education for Sustainable Development (ESD), values in geographical and transformative learning.

\section{Co-author}

Ferguson, René

Dr René Ferguson is a lecturer in Democratic Citizenship and Human Rights education, with specific interests in diversity studies, transformative learning and reflexive praxis.

\section{Co-author}

\section{Goldschagg, Paul}

Paul Goldschagg holds a PhD from Stellenbosch University. His research interests include the non-auditory effects of noise on people; classroom noise and the effects on teaching and learning; and teacher Education for Sustainable Development (ESD).

\section{Co-author}

Mandikonza, Caleb

Caleb Mandikonza holds a $\mathrm{PhD}$ in Environmental Education. His research interests are reflexive practice and professional development in teaching in Education for Sustainable Development (ESD), including student engagement, agency, climate change education, cultural heritage, cumulative knowledge building, assessment, and pedagogy in science teacher education. 


\section{Percentage contribution}

\begin{tabular}{|l|l|c|}
\hline \multirow{4}{*}{ Areas of contribution } & Author & $\begin{array}{c}\text { Percentage } \\
\text { contribution }\end{array}$ \\
\hline \multirow{4}{*}{ Conception or design of the paper, theory or key argument } & Thenga & $70 \%$ \\
\cline { 2 - 3 } & Goldschagg & $10 \%$ \\
\cline { 2 - 3 } & Ferguson & $10 \%$ \\
\cline { 2 - 3 } & Mandikonza & $10 \%$ \\
\hline Data collection & Thenga & $100 \%$ \\
\hline \multirow{4}{*}{ Analysis and interpretation } & Thenga & $70 \%$ \\
\cline { 2 - 3 } & Goldschagg & $10 \%$ \\
\cline { 2 - 3 } & Ferguson & $10 \%$ \\
\cline { 2 - 3 } & Mandikonza & $10 \%$ \\
\hline \multirow{4}{*}{ Drafting the paper } & Thenga & $70 \%$ \\
\cline { 2 - 3 } & Goldschagg & $10 \%$ \\
\cline { 2 - 3 } & Ferguson & $10 \%$ \\
\cline { 2 - 3 } & Mandikonza & $10 \%$ \\
\hline \multirow{5}{*}{ Critical review of paper } & Thenga & $40 \%$ \\
\cline { 2 - 3 } & Goldschagg & $20 \%$ \\
\cline { 2 - 3 } & Ferguson & $20 \%$ \\
\cline { 2 - 3 } & Mandikonza & $20 \%$ \\
\hline
\end{tabular}

\section{References}

Anderson, A. (2012). Climate change education for mitigation and adaptation, Journal of Education for Sustainable Development, 6(2), 19119-206.

Avalos, B. (2011). Teacher professional development in teaching and teacher education over ten years, Teaching and Teacher Education, 27, 10-20.

Borg, C., Gericke, N., Höglund, H. \& Bergman, E. (2012). Subject- and experience-bound differences in teachers' conceptual understanding of sustainable development, Environmental Education Research, 20(4), 526-551.

Boyatzis, R.E. (1998). Transforming qualitative information: Thematic analysis and code development. Thousand Oaks: Sage.

Codero, E.C., Centeno, D. \& Todd, A.M. (2020). The role of climate change education on individual lifetime carbon emissions, PLoS ONE, 15(2), 1-23.

Cranton, P. \& King, K.P. (2003). Transformative learning as a professional development goal. New Directions for Adult and Continuing Education, 98, 31-37. 
Creswell, J.W. (2012). Educational research: Planning, conducting, and evaluating quantitative and qualitative research. Boston: Pearson.

Darling-Hammond, L. (2010). Teacher education and the American future. Journal of Teacher Education, 6(1-2), 35-47.

Department of Basic Education. (2011). Curriculum and Assessment Policy Statement (CAPS). Geography Grade 10-12. Pretoria.

Ferguson, T. (2019). Climate change education for sustainable development. In W.L. Filho (Ed.), Encyclopedia of Sustainability in Higher Education. Switzerland: Springer.

Ferreira, J.G. (2014). The contribution of a particular 'Kids in Parks' programme to the professional development of teachers. South Africa Journal of Education, 34(2), 1-13.

Fundisa for Change. (2013). Introductory Core Text. Environmental Learning Research Centre, Rhodes University, Grahamstown.

IPCC. (2015). Future work of the IPCC: Consideration of the recommendations by the task group on Future Work of the IPCC, Geneva.

Javadi, M. \& Zarea, K. (2016). Understanding thematic analysis and its pitfalls. Journal of Client Care, 1(1), 34-40.

Kalumba, E. (2017). Education quality and the introduction of new teaching methods. In H. Lotz-Sisitka, O. Shumba, J. Lupele \& D. Wilmot (Eds.), Schooling for Sustainable Development in Africa. Switzerland: Springer.

Laurie, R., Nonoyama-Tarumi, Y., McKeown, R. \& Hopkins, C. (2016). Contributions of Education for Sustainable Development (ESD) to Quality Education: A Synthesis of Research, Research, 10(2), 226 -242.

Merriam, S.B. (2002) Introduction to qualitative research. In S.B. Merriam and Associates (Eds.), Qualitative research in practice: Examples for discussion and analyses. San Francisco: Jossey-Bass.

Mezirow, J. (1991). Transformative dimensions of adult learning. San Francisco: Jossey-Bass.

Mezirow, J. (1997). Transformative learning: Theory to practice. New Directions for Adult and Continuing Education, 74, 5-12.

Mezirow, J. (2000). Learning to think like an adult: Core concepts of transformative learning theory. In J. Mezirow and Associates (Eds.), Learning as transformation: Critical perspectives on theory in progress (pp.3-33). San Francisco: Jossey-Bass.

Mezirow, J. (2003). Transformative learning as discourse. Journal of Transformative Education, 1(1), 58-63.

Mokuku, T. \& Jobo, M. (2017). Education quality and the introduction of new teaching methods. In H. Lotz-Sisitka, O. Shumba, J. Lupele \& D. Wilmont (Eds.), Schooling for Sustainable Development in Africa. Switzerland: Springer.

Monroe, M.C., Plate, R.R., Oxarart, A., Bowers, A. \& Chaves, W.A. (2019). Identifying effective climate change education strategies: A systematic review of the research, Environmental Education Research, 5(6), 791-812.

Nawab, A. (2017). What difference could in-service training make? Insights from a public school in Pakistan. Teacher Development, 21(1), 142-159. 
Ngulube, P. (2015). Qualitative analysis and interpretation: systemic search for meaning. In E.R. Mathipa \& M.T. Gumbo (Eds.), Addressing research challenges: Making headway for developing researchers. Noordwyk: Mosala-MASEDI, pp.131-156.

Ono, Y. \& Ferreira, J. (2010). A case study of continuing teacher development through lesson study in South Africa. South African Journal of Education, 30, 59-74.

Patton, K., Parker, M. \& Tannehill, D. (2015). Helping teachers help themselves: Professional development that makes a difference. NASSP Bulletin, 99(1), 26-42.

Raselimo, M. \& Wilmot, D. (2013). Geography teachers' interpretation of a curriculum reform initiative: the case of the Lesotho Environmental Education Support Project (LEESP). South African Journal of Education, 33(1), 1-15.

Smith, M. (2013). How does education for sustainable development relate to geography education? In D. Lambert \& M. Jones (Eds.), Debates in Geography Education. London: Routledge, pp.1-14.

Stevenson, R.B., Nicholls, J. \& Whitehouse, H. (2017). What is climate change education? Curriculum Perspectives, 37, 67-71.

Steyn, G.M. (2008). Continuing professional development of teachers in South Africa and social learning systems: conflicting conceptual frameworks. Koers, 73(1), 15-31.

Thenga, M. (2020). The influence of a short intervention programme on professional development of in-service teachers in Education for sustainable development in secondary schools. Unpublished doctoral thesis, University of the Witwatersrand, Johannesburg.

UNESCO. (2012). Education for Sustainable Development Sourcebook. Paris: UNESCO.

Vogel, C., Misser, S. \& Vallabh, P. (2013). Teaching Climate Change. Fundisa for Change programme. Environmental Learning Research Centre, Rhodes University, Grahamstown.

Vohra, V. (2014). Using multiple case study design to decipher contextual leadership behaviours in Indian organisations, Electronic Journal of Business Research Methods, 12(1), 54-65. 